\title{
Locally Advanced Oropharyngeal Squamous Cell Carcinoma
}

National Cancer Institute

\section{Source}

National Cancer Institute. Locally Advanced Oropharyngeal Squamous Cell Carcinoma. NCl Thesaurus. Code C162881.

An oropharyngeal squamous cell carcinoma that has spread from its original site of growth to nearby tissues or lymph nodes. 